\title{
Evaluasi Karakter Agronomi dan Analisis Kekerabatan 10 Genotipe Lokal Kacang Hijau (Vigna radiata $\mathrm{L}$. Wilczek)
}

\section{Evaluation of Agronomy's Character and Cluster Analysis of 10 Genotype Indigenous Mungbean} (Vigna radiata L. Wilczek)

\author{
Indah Dwi Putri ${ }^{1}$, Surjono Hadi Sutjahjo ${ }^{1 *}$, dan Edizon Jambormias ${ }^{2}$ \\ ${ }^{1}$ Departemen Agronomi dan Hortikultura, Fakultas Pertanian, Institut Pertanian Bogor \\ Jl. Meranti, Kampus IPB Darmaga, Bogor 16680, Indonesia \\ Telp.\&Faks.+62-251-8629353 e-mail agronipb@indo.net.id \\ ${ }^{2}$ Jurusan Budidaya Pertanian, Fakultas Pertanian, Universitas Pattimura, Ambon \\ *)Penulis untuk korespondensi : surjonohadisutjahjo@yahoo.co.id \\ Disetujui 24 Desember 2013/ Published online 13 Februari 2014
}

\begin{abstract}
ABSTRAK
Kacang hijau (Vigna radiata L. Wilczek) merupakan salah satu tanaman Leguminosae yang cukup penting di Indonesia. Permasalahan yang sering muncul pada budidaya kacang hijau adalah tidak serempaknya panen sehingga membutuhkan waktu dan tenaga kerja yang lebih banyak. Tujuan penelitian ini adalah untuk mengevaluasi karakter agronomi 10 genotipe lokal kacang hijau dan menganalisis jarak genetik antar genotipe-genotipe tersebut berdasarkan karakter kuantitatif dan kualitatif. Percobaan dilaksanakan di Kebun Percobaan IPB Leuwikopo Dramaga, Bogor pada bulan April hingga Agustus 2013, dalam rancangan acak kelompok (RAK) dengan faktor tunggal yang terdiri atas 10 genotipe kacang hijau lokal dan satu varietas nasional sebagai pembanding dengan tiga ulangan. Hasil penelitian menunjukkan bahwa genotipe-genotipe yang diuji berbeda nyata dengan pembanding pada komponen pertumbuhan, komponen umur tanaman, dan komponen produksi. Genotipe LL3 merupakan genotipe dengan keragaan terbaik (berdasarkan parameter: komponen produksi, komponen umur tanaman, dan komponen keserempakan panen), diikuti LLA, LWL, dan LKH. Berdasarkan analisis jarak genetik, genotipe-genotipe yang diuji mengelompok menjadi empat kelompok (berdasarkan karakter kuantitatif) dan tiga kelompok (berdasarkan karakter kualitatif).
\end{abstract}

Kata kunci: jarak genetik, kacang hijau, karakter agronomi, panen serempak

\begin{abstract}
One kind of Indonesian important Leguminosae is mungbean (Vigna radiata L. Wilczek). The difference of time harvesting become a serious problem in mungbean cultivation because it needs more labour and time consuming. The objective of this research are evaluating agronomical characteristic of 10 indigenous mungbean genotypes and analyzing genetic distance between those genotypes, based on quantitative and qualitative characteristics. The experiment was carried out at Leuwikopo Experimental Field, Bogor Argricultural University, Dramaga, Bogoron April to August 2013. Design of experiment that use in this research was random block design with one factor that consist of 10genotypes indigenous mungbean and one national variety as controlin three replication. The result showed thatall genotypes were significantly different ingrowth component, plant age component, and production component as contrast. LL3 genotypefound as the best variability (based on production component, plant age component, and synchronized time harvestingcomponent), followed by LL4, LWL, and LKH. Analysis of genetic distance resulted four groups based on quantitative characters and three groups based on qualitative characters by all genotypes.
\end{abstract}

Keywords: agronomy's character, genetic distance, mungbean, unison harvest 


\section{PENDAHULUAN}

Kacang hijau (Vigna radiata $\mathrm{L}$. Wilczek) merupakan salah satu tanaman Leguminosae yang cukup penting di Indonesia. Indonesia merupakan penghasil kacang hijau terbesar ke empat di dunia setelah India, Thailand, dan Cina, dengan luas panen sekitar 300000 ha tahun $^{-1}$ (Puslittan 2012a). Berdasarkan BPS (2012) produktivitas kacang hijau mengalami peningkatan dari tahun 2008 hingga 2012 yaitu berturut-turut sebesar 10.72, 10.91, 11.30, 11.48, dan $11.60 \mathrm{ku} \mathrm{ha}^{-1}$.

Tanaman ini merupakan komoditas penting secara agronomi, ekonomi, maupun gizi dan kesehatan. Kelebihan dari segi agronomi yaitu: mudah dibudidayakan, dapat ditanam pada tanah yang kurang subur, lebih tahan kekeringan, dan dapat dipanen pada umur 60 hari, sedangkan dari segi ekonomi yaitu: harga jual relatif tinggi dan stabil (Puslittan 2012a). Kacang hijau merupakan sumber protein nabati, vitamin (A, B1, dan C), dan beberapa mineral. Jenis karbohidratnya mudah dicerna sehingga cocok untuk makanan tambahan bayi dan anak balita. Biji maupun tepung kacang hijau banyak digunakan dalam berbagai bentuk pangan, seperti bubur, roti, dan mi. Sementara itu kecambah kacang hijau (tauge) yang banyak mengandung vitamin E digunakan untuk sayur (Purwono dan Purnamawati 2008).

Komposisi rata-rata dari biji yang sudah kering adalah 60-65\% karbohidrat, 25-28\% protein, $3.5-4.5 \%$ serat, dan $1-1.5 \%$ lemak. Sama halnya seperti sebagian besar kacang-kacangan lainnya, protein yang tertinggi pada kacang hijau adalah lysine yaitu $6.5-8 \%$ dan bijinya memberikan pelengkap protein yang sangat baik untuk sereal berbasis diet. Biji yang sudah kering dapat dimakan utuh, dimasak atau difermentasi, dikeringkan, digiling, dan ditumbuk menjadi tepung (Lawn dan Imrie 1991).

Banyaknya manfaat dan tingginya kandungan gizi pada kacang hijau sehingga dapat dijadikan alternatif makanan. Permasalahan yang sering muncul pada budidaya tanaman ini adalah tidak serempaknya panen sehingga membutuhkan waktu dan tenaga kerja yang lebih banyak. Untuk mengatasi masalah tersebut maka perlu dirakit varietas-varietas kacang hijau dengan produksi tinggi dan periode panen lebih singkat serta serempak. Evaluasi terhadap 10 genotipe lokal kacang hijau diharapkan dapat mendeskripsikan keragaan masing-masing genotipe sehingga dapat dipertimbangkan untuk dijadikan sebagai bahan tetua persilangan. Tujuan penelitian adalah mengevaluasi karakter agronomi 10 genotipe lokal kacang hijau dan menganalisis jarak genetik genotipe-genotipe berdasarkan karakter kuantitatif dan kualitatif.

\section{BAHAN DAN METODE}

Percobaan lapang telah dilaksanakan di Kebun Percobaan IPB Leuwikopo Dramaga, Bogor, dari bulan April sampai Agustus 2013. Bahan tanam yang digunakan dalam percobaan lapang adalah benih kacang hijau yang terdiri atas: 10 genotipe lokal koleksi Bagian Genetika dan Pemuliaan Tanaman IPB dan satu varietas nasional. Genotipe-genotipe lokal tersebut yaitu: kacang hijau lokal Lombok NTB 1 (LL1), kacang hijau lokal Lombok NTB 2 (LL2), kacang hijau lokal Lombok NTB 3 (LL3), kacang hijau lokal Lombok NTB 4 (LL4), kacang hijau Kefaminano NTT 1 (KFM-1), kacang hijau Kefaminano NTT 2 (KFM-2), kacang hijau Kepulauan Meranti, Kepulauan Riau (MRT), kacang hijau lokal Maluku Selatan Mamasa Lere Butnem (LWL), kacang hijau lokal Maluku Selatan Lasafu Lere Butsiw Fernamamas (LKF), dan kacang hijau lokal Maluku Selatan Lasafu Lere Butsiw (LKH). Varietas nasional tersebut adalah Vima 1 (Vima) dan dijadikan sebagai pembanding. Pupuk yang digunakan adalah Urea $76 \mathrm{~kg} \mathrm{ha}^{-1}$, SP-36 $100 \mathrm{~kg}$ ha $^{-1}$, dan $\mathrm{KCl} 75 \mathrm{~kg} \mathrm{ha}^{-1}$. Furadan 3 GR digunakan untuk melindungi benih supaya tidak dimakan serangga. Alat-alat yang digunakan adalah alatalat pertanian (seperti cangkul, kored, dan ember), meteran, amplop, label, dan timbangan.

Rancangan yang digunakan adalah Rancangan Acak Kelompok (RAK) dengan faktor tunggal yang terdiri atas 11 genotipe kacang hijau dengan tiga ulangan yang ditempatkan secara acak sehingga terdapat 33 satuan percobaan. Masingmasing satuan percobaan dipilih 5 tanaman sebagai tanaman contoh sehingga terdapat 165 satuan amatan.

Data kuantitatif yang diperoleh dianalisis menggunakan analisis ragam dengan uji $\mathrm{F}$ pada taraf nyata $5 \%$. Jika uji $\mathrm{F}$ berpengaruh nyata maka nilai tengah diuji lanjut dengan uji Dunnet pada taraf nyata 5\%. Program SAS versi 9.1.3 digunakan untuk melakukan analisis ragam (anova) dan uji lanjut Dunnet. Data kuantitatif dan kualitatif yang diperoleh dianalisis menggunakan analisis gerombol untuk mengetahui hubungan kekerabatan antar genotipe lokal yang diuji. Analisis gerombol (cluster analysis) menggunakan metode Euclidan untuk karakter kuantitatif dan metode Dice untuk karakter kualitatif, dengan bantuan program SPSS versi 16 
yang selanjutnya tersaji dalam bentuk dendogram (Jambormias 2011). Karakter kuantitatif yang dimasukkan kedalam perhitungan jarak genetik adalah karakter yang memiliki pengaruh genotipe anova nyata dan karakter kualitatif yang dimasukkan kedalam perhitungan adalah karakter yang polimorfik.

Pelaksanaan penelitian dimulai dengan membersihkan lahan dari gulma, kemudian persiapkan tiga kelompok berukuran masingmasing $18 \mathrm{~m} \times 5 \mathrm{~m}$. Penanaman dilakukan dengan cara ditanam dalam baris, dua benih per lubang. Jarak tanam yang digunakan adalah $60 \mathrm{~cm} x 40$ $\mathrm{cm}$. Pemupukan dilakukan dengan cara penugalan. Pupuk Urea diberikan pada saat tanam dan umur 3 MST (Minggu Setelah Tanam), sedangkan SP-36 dan KCl diberikan saat tanam. Pengendalian gulma dilakukan setiap dua minggu sekali. Pengendalian hama dan penyakit tanaman dilakukan saat ada gejala. Pemanenan dilakukan jika polong telah berwarna hitam atau coklat kehitaman. Pemanenan dilakukan setiap hari sejak panen pertama. Benih hasil panen masing-masing tanaman contoh diletakkan secara terpisah dalam amplop dan diberi label. Benih-benih tersebut kemudian dijemur dan ditimbang sesuai dengan pengamatan yang dibutuhkan.

Pengamatan dilakukan terhadap karakterkarakter kuantitatif dan kualitatif. Karakter kuantitatif yang diamati meliputi komponen pertumbuhan (tinggi tanaman dan derajat indeterminasi (DI)), komponen produksi (jumlah polong bernas per tanaman, jumlah biji bernas per tanaman, dan bobot 100 butir), komponen umur tanaman (umur berbunga dan umur panen), dan komponen keserempakan panen (lama hari panen dan indeks panen serempak (IPS)). Tinggi tanaman yang diamati adalah tinggi tanaman pada saat berbunga dan saat panen terakhir. Derajat indeterminasi dihitung menurut persamaan (Khattak et al. 2001):

$$
D I=\frac{T T p-T T b}{T T p} \times 100
$$

dimana:

TTp = tinggi tanaman pada saat panen terakhir $\mathrm{TTb}=$ tinggi tanaman pada saat berbunga
Umur berbunga yang diamati adalah umur berbunga $50 \%$ dan umur berbunga $100 \%$. Indeks panen serempak adalah ukuran keserempakan panen suatu genotipe dari panen pertama hingga panen terakhir (ukuran relatif keserempakan panen), yang dihitung menurut persamaan (Jambormias et al. 2013):

$I P S=\frac{1}{\sum_{i=1}^{d} y_{i}} \sum_{i=1}^{d} \frac{y_{i}}{d_{i}+1}=\frac{1}{\sum_{i=1}^{d} y_{i}}\left[\frac{y_{1}}{d_{1}+1}+\frac{y_{2}}{d_{2}+1}+L+\frac{y_{h}}{d_{h}+1}\right]$

dimana:

$y_{i}=$ bobot biji yang dipanen pada hari panen ke-i, untuk $\mathrm{i}=1,2, \ldots, \mathrm{d}$.

$d_{i}=$ lama hari panen hingga hari panen ke-i yang menghasilkan $y_{1}$

$y_{l}=$ bobot biji pada hari panen ke-i yang menghasilkan bobot paling tinggi

Karakter kualitatif yang diamati pada percobaan adalah warna hipokotil, warna mahkota bunga sebelum mekar, warna bunga, warna polong masak, warna biji, dan kilau permukaan biji. Warna hipokotil diamati pada umur 10 hari setelah tanam (HST). Warna mahkota bunga sebelum mekar dan warna bunga diamati pada saat $50 \%$ berbunga. Warna polong masak diamati pada saat menjelang panen. Warna biji dan kilau permukaan biji diamati setelah panen (PPI 2007).

\section{HASIL DAN PEMBAHASAN}

\section{Keragaan Karakter Kuantitatif}

Genotipe-genotipe kacang hijau memperlihatkan perbedaan keragaan berdasarkan karakter kuantitatif. Hasil analisis ragam memperlihatkan adanya perbedaan keragaan sangat nyata berdasarkan umur berbunga $50 \%$, tinggi tanaman saat berbunga, tinggi tanaman saat panen terakhir, lama hari panen, dan jumlah polong bernas per tanaman (Tabel 1). 
Tabel 1. Analisis ragam karakter-karakter kuantitatif dari 11 genotipe kacang hijau

\begin{tabular}{|c|c|c|c|c|c|c|}
\hline No. & Karakter & \multicolumn{2}{|c|}{ F hitung } & $\mathrm{KK}(\%)$ & $\bar{x} \pm s$ & $\mathrm{R}^{2}(\%)$ \\
\hline 1 & Tinggi tanaman saat berbunga & 12.44 & $* *$ & 23.55 & $31.50 \pm 35.50$ & 86.87 \\
\hline 2 & Tinggi tanaman saat panen terakhir & 13.78 & $* *$ & 16.91 & $48.10 \pm 38.00$ & 87.89 \\
\hline 3 & Jumlah polong bernas per tanaman & 6.40 & $* *$ & 29.40 & $6.00 \pm 6.00$ & 80.77 \\
\hline 4 & Jumlah biji bernas per tanaman & 4.50 & tn & 52.53 & $41.00 \pm 40.00$ & 75.67 \\
\hline 5 & Bobot 100 butir & 2.13 & $\operatorname{tn}$ & 33.06 & $4.09 \pm 1.23$ & 64.72 \\
\hline 6 & Umur berbunga $50 \%$ & 6.35 & $* *$ & 10.20 & $42.00 \pm 14.00$ & 77.53 \\
\hline 7 & Umur berbunga $100 \%$ & 1.39 & tn & 31.93 & $62.00 \pm 20.00$ & 47.56 \\
\hline 8 & Umur panen & 1.51 & tn & 33.20 & $60.00 \pm 6.00$ & 55.15 \\
\hline 9 & Lama hari panen & $<0.0001$ & $* *$ & 26.37 & $6.63 \pm 6.63$ & 92.43 \\
\hline 10 & Indeks panen serempak & 1.80 & $\operatorname{tn}$ & 47.52 & $0.95 \pm 0.06$ & 62.77 \\
\hline
\end{tabular}

**: berpengaruh sangat nyata pada taraf $1 \%$, tn: tidak berpengaruh nyata; KK= Koefisien Keragaman; $\bar{x} \pm s=$ nilai tengah \pm simpangan baku; $R^{2}=$ Koefisien Determinasi.

\section{Komponen Pertumbuhan}

Tinggi tanaman yang diamati adalah tinggi tanaman saat berbunga dan saat panen terakhir. Analisis ragam memperlihatkan adanya perbedaan pertumbuhan baik berdasarkan karakter tinggi tanaman saat berbunga maupun saat panen terakhir. Hasil analisis memperlihatkan bahwa tinggi tanaman saat berbunga dan saat panen terakhir berkisar antara 17.3-67 cm dan 23.1-86.1 $\mathrm{cm}$ dengan rata-rata masing-masing sebesar 31.5 $\mathrm{cm}$ dan $48.1 \mathrm{~cm}$ (Tabel 2).

Tabel 2. Hasil rataan tinggi tanaman saat berbunga dan saat panen terakhir dari 11 genotipe kacang hijau

\begin{tabular}{cccc}
\hline Genotipe & $\begin{array}{c}\text { Tinggi tanaman saat } \\
\text { berbunga }(\mathrm{cm})\end{array}$ & $\begin{array}{c}\text { Tinggi tanaman saat } \\
\text { panen terakhir }(\mathrm{cm})\end{array}$ & Derajat indeterminasi \\
\hline KFM-1 & $26.50 \mathrm{a}$ & $55.30 \mathrm{~b}$ & 52.08 \\
KFM-2 & $24.90 \mathrm{a}$ & $43.60 \mathrm{~b}$ & 42.89 \\
LKF & $52.80 \mathrm{~b}$ & $61.10 \mathrm{~b}$ & 13.58 \\
LKH & $67.00 \mathrm{~b}$ & $86.10 \mathrm{~b}$ & 22.18 \\
LL1 & $23.30 \mathrm{a}$ & $39.50 \mathrm{a}$ & 41.01 \\
LL2 & $35.60 \mathrm{~b}$ & $59.40 \mathrm{~b}$ & 40.07 \\
LL3 & $25.10 \mathrm{a}$ & $32.80 \mathrm{a}$ & 23.48 \\
LL4 & $30.10 \mathrm{a}$ & $54.00 \mathrm{~b}$ & 44.26 \\
LWL & $21.50 \mathrm{a}$ & $35.90 \mathrm{a}$ & 40.11 \\
MRT & $22.90 \mathrm{a}$ & $38.00 \mathrm{a}$ & 39.74 \\
\hline Vima & $\mathbf{1 7 . 3 0} \mathbf{a}$ & $\mathbf{2 3 . 1 0} \mathbf{a}$ & $\mathbf{2 5 . 1 1}$ \\
\hline
\end{tabular}

Angka yang diikuti dengan huruf yang sama pada kolom yang sama menunjukkan hasil yang tidak berbeda nyata dengan pembanding Vima.

Hasil uji lanjut menunjukkan bahwa karakter tinggi tanaman saat berbunga berbeda nyata antara Vima dengan LKF, LKH, dan LL2, dan antara Vima dengan KFM-1, KFM-2, LKF, LKH, LL2, dan LL4saat panen terakhir. Terdapat tiga genotipe yang berbeda nyata untuk kedua karakter tersebut yaitu LKF, LKH, dan LL2. Ketiga genotipe ini lebih tinggi dibandingkan Vima, begitu juga dengan genotipe lokal lainnya. Hal ini menunjukkan bahwa genotipe lokal yang diuji cenderung lebih tinggi dibanding varietas Vima. Genotipe LKH merupakan genotipe tertinggi saat berbunga maupun saat panen terakhir, masing-masing sebesar $67 \mathrm{~cm}$ dan 86.1 $\mathrm{cm}$, lebih baik dibandingkan Vima dan rata-rata populasi. Menurut Musalamah dan Anwari (2007), tinggi tanaman kacang hijau berkisar antara 75-110 cm dengan rata-rata sebesar $96 \mathrm{~cm}$, sedangkan Gumabo (2007), menyebutkan kisaran yang lebih rendah yaitu antara $15.55-62.33 \mathrm{~cm}$ dengan rata-rata sebesar $47.9 \mathrm{~cm}$. Hasil penelitian ini memiliki kisaran dan rata-rata tinggi tanaman yang lebih rendah dibandingkan kedua penelitian tersebut. Begitu juga dengan varietas pembanding, 
tinggi tanaman pada penelitian ini sebesar 23.1 $\mathrm{cm}$, lebih rendah dibandingkan deskripsi varietas sebesar $53 \mathrm{~cm}$.

Derajat indeterminasi genotipe-genotipe yang diuji berkisar antara 13.58-52.08 dengan rata-rata 34.95 (Tabel 2). Genotipe LKF memiliki derajat indeterminasi paling baik yaitu 13.58, lebih baik dibandingkan dengan Vima dan ratarata populasi. Selain itu genotipe LKH dan LL3 juga memiliki derajat indeterminasi yang lebih baik dibandingkan Vima. Hal ini menunjukkan bahwa genotipe-genotipe yang diuji cenderung determinit, karena perubahan tinggi tanaman tidak terlalu besar. Menurut Khattak et al. (2004), seleksi untuk tipe tumbuh determinit pada tinggi tanaman harus ditunda hingga generasi selanjutnya, ketika segregasi yang diinginkantelah tersedia. Interaksi gen aditif, dominan, dan digenic non-allelic ditemukan signifikan untuk derajat indeterminasi pada polong masak (panen serempak) dan derajat indeterminasi pada tinggi tanaman (tipe tumbuh determinit).

\section{Komponen Produksi}

Hasil analisis ragam memperlihatkan adanya perbedaan antar genotipe-genotipe berdasarkan karakter jumlah polong bernas per tanaman, sedangkan untuk karakter jumlah biji bernas per tanaman dan bobot 100 butir tidak berpengaruh nyata. Kisaran jumlah polong bernas per tanaman dan jumlah biji bernas per tanaman berturut-turut adalah 3-12 polong dan 11-81 biji dengan rata-rata masing-masing sebesar 6 polong dan 41 biji (Tabel 3). Bobot 100 butir mempunyai kisaran antara 2.86-5.25 gram dengan rata-rata 4.09 gram (Tabel 3).

Jumlah polong bernas per tanaman dan jumlah biji bernas per tanaman sangat menentukan produktivitas tanaman kacang hijau. Hasil uji lanjut menunjukkan bahwa karakter jumlah polong bernas per tanaman berbeda nyata antara LL3 dengan Vima. Genotipe LL3 memiliki jumlah polong bernas per tanaman paling banyak yaitu 12 polong, lebih baik bila dibandingkan dengan Vima dan rata-rata populasi. Selain itu genotipe LL2 dan LL4 memiliki jumlah polong bernas per tanaman sebesar 8 polong, yang lebih banyak dibandingkan Vima sebesar 7 polong. Menurut Anwari dan Iswanto (2004), rata-rata jumlah polong per tanaman kacang hijau adalah 16 polong, sedangkan Musalamah dan Anwari (2007), menyebutkan kisaran yang lebih besar yaitu antara 11-51 polong dengan rata-rata sebesar 29.48 polong. Hasil penelitian ini memiliki kisaran dan rata-rata jumlah polong bernas per tanaman yang lebih sedikit dibandingkan kedua penelitian tersebut.

Tabel 3. Hasil rataan jumlah polong bernas per tanaman, jumlah biji bernas per tanaman, dan bobot 100 butir dari 9 genotipe kacang hijau

\begin{tabular}{|c|c|c|c|}
\hline Genotipe & Jumlah polong bernas per tanaman & $\begin{array}{c}\text { Jumlah biji bernas per } \\
\text { tanaman }\end{array}$ & $\begin{array}{l}\text { Bobot } 100 \text { butir } \\
\text { (gram) }\end{array}$ \\
\hline KFM-1 & $5.00 \quad \mathrm{a}$ & $48.00 \mathrm{a}$ & $3.73 \mathrm{a}$ \\
\hline KFM-2 & $3.00 \mathrm{a}$ & $12.00 \mathrm{a}$ & $2.86 \mathrm{a}$ \\
\hline LL1 & $5.00 \quad \mathrm{a}$ & $16.00 \mathrm{a}$ & $3.71 \mathrm{a}$ \\
\hline LL2 & $8.00 \mathrm{a}$ & $57.00 \mathrm{a}$ & $4.93 \mathrm{a}$ \\
\hline LL3 & $12.00 \mathrm{~b}$ & $81.00 \mathrm{a}$ & $3.78 \mathrm{a}$ \\
\hline LL4 & $8.00 \mathrm{a}$ & $66.00 \mathrm{a}$ & $5.25 \mathrm{a}$ \\
\hline LWL & $5.00 \mathrm{a}$ & $24.00 \mathrm{a}$ & $3.79 \mathrm{a}$ \\
\hline MRT & $4.00 \mathrm{a}$ & $11.00 \mathrm{a}$ & $3.97 \mathrm{a}$ \\
\hline Vima & $7.00 \quad a$ & 53.00 a & $4.81 \mathrm{a}$ \\
\hline
\end{tabular}

Angka yang diikuti dengan huruf yang sama pada kolom yang sama menunjukkan hasil yang tidak berbeda nyata dengan pembanding Vima.

Genotipe LL3 memiliki jumlah polong bernas per tanaman dan jumlah biji bernas per tanaman yang terbaik tetapi bobot 100 butir lebih rendah dibandingkan Vima. Hal ini berarti LL3 memiliki biji yang berukuran kecil sehingga bobot 100 butirnya rendah. Sedangkan genotipe LL2 dan LL4 memiliki jumlah polong bernas per tanaman dan jumlah biji bernas per tanaman yang lebih sedikit dibandingkan LL3 tetapi bobot 100 butir lebih berat dibandingkan LL3. Hal ini berarti LL2 dan LL4 memiliki biji yang berukuran lebih besar dibandingkan LL3 dan genotipe lainnya serta Vima. Vima merupakan varietas kacang hijau hasil pemuliaan sehingga genotipe lokal yang memiliki produksi lebih besar dari Vima 
berpotensi untuk dikembangkan dan dijadikan bahan tetua persilangan.

\section{Komponen Umur Tanaman}

Umur berbunga yang diamati adalah umur berbunga $50 \%$ dan umur berbunga $100 \%$. Analisis ragam memperlihatkan genotipe-genotipe yang diuji berpengaruh sangat nyata untuk karakter umur berbunga $50 \%$, sedangkan untuk karakter umur berbunga $100 \%$ dan umur panen tidak berpengaruh nyata. Umur berbunga $50 \%$ dan umur berbunga $100 \%$ berkisar antara 34-55 hari dan 50-82 hari,masing-masing dengan rataratasebesar 42 hari dan 62 hari (Tabel 4). Umur panen berkisar antara 55-66 hari dengan rata-rata 60 hari (Tabel 4). Genotipe LKF dan LKH tidak diketahui umur panen karena genotipe tersebut tidak dapat dipanen karena sudah terkena penyakit sebelum dilakukan panenan. Oleh sebab itu, kedua genotipe lokal ini kemungkinan memiliki umur panen lebih panjang dari genotipe LWL yang dipanen pada umur 66 hari.

Genotipe-genotipe yang diuji memiliki umur berbunga $50 \%$ lebih lama dibandingkan Vima tetapi pada umur berbunga $100 \%$ memiliki umur yang relatif sama dengan Vima. Tampak bahwa karakter umur berbunga 50\% berbeda nyata antara Vima dengan LKF dan LKH. Perbedaan LKF dan LKH ini bernilai negatif (tidak diinginkan) karena umur berbunga yang diharapkan adalah yang lebih pendek sedangkan LKF dan LKH memiliki umur berbunga yang panjang. Genotipe LL3 memiliki umur berbunga $50 \%$ terbaik yaitu 34 hari, lebih pendek dibandingkan Vima dan rata-rata populasi. Sementara genotipe lainnya memiliki umur berbunga 50\% yang lebih panjang dibandingkan Vima. Menurut Gumabo (2007), umur berbunga $50 \%$ tanaman kacang hijau berkisar antara 3744.5 hari dengan rata-rata sebesar 39.75 hari. Hasil penelitian ini memiliki kisaran dan rata-rata umur berbunga $50 \%$ yang lebih pendek dibandingkan penelitian tersebut. Berbeda dengan varietas pembanding, umur berbunga $50 \%$ pada penelitian ini sebesar 37 hari, lebih lama dibandingkan deskripsi varietas sebesar 33 hari.

Genotipe LL3 memiliki umur berbunga $50 \%$ sebesar 34 hari, lebih pendek dibandingkan Vima sebesar 37 hari tetapi memiliki umur panen sebesar 61 hari, lebih lama dibandingkan Vima sebesar 55 hari. Hal ini berarti genotipe LL3 memiliki waktu pengisian biji yang lebih lama dibandingkan Vima.

Tabel 4. Hasil rataan umur berbunga 50\%, umur berbunga 100\%, dan umur panen dari 11 genotipe kacang hijau

\begin{tabular}{cccc}
\hline Genotipe & $\begin{array}{c}\text { Umur berbunga } \\
50 \% \text { (hari) }\end{array}$ & $\begin{array}{c}\text { Umur berbunga } \\
100 \% \text { (hari) }\end{array}$ & Umur panen (hari) \\
\hline KFM-1 & $42.00 \mathrm{a}$ & $61.00 \mathrm{a}$ & $61.00 \mathrm{a}$ \\
KFM-2 & $40.00 \mathrm{a}$ & $53.00 \mathrm{a}$ & $61.00 \mathrm{a}$ \\
LKF & $49.00 \mathrm{~b}$ & $79.00 \mathrm{a}$ & $>=66$ \\
LKH & $55.00 \mathrm{~b}$ & $82.00 \mathrm{a}$ & $>=66$ \\
LL1 & $38.00 \mathrm{a}$ & $63.00 \mathrm{a}$ & $61.00 \mathrm{a}$ \\
LL2 & $45.00 \mathrm{a}$ & $68.00 \mathrm{a}$ & $62.00 \mathrm{a}$ \\
LL3 & $34.00 \mathrm{a}$ & $50.00 \mathrm{a}$ & $61.00 \mathrm{a}$ \\
LL4 & $38.00 \mathrm{a}$ & $50.00 \mathrm{a}$ & $61.00 \mathrm{a}$ \\
LWL & $38.00 \mathrm{a}$ & $52.00 \mathrm{a}$ & $66.00 \mathrm{a}$ \\
MRT & $39.00 \mathrm{a}$ & $73.00 \mathrm{a}$ & $61.00 \mathrm{a}$ \\
\hline Vima & $\mathbf{3 7 . 0 0} \mathbf{a}$ & $\mathbf{5 0 . 0 0} \mathbf{a}$ & $\mathbf{5 5 . 0 0} \mathbf{a}$
\end{tabular}

Angka yang diikuti dengan huruf yang sama pada kolom yang sama menunjukkan hasil yang tidak berbeda nyata dengan pembanding Vima.

\section{Komponen Keserempakan Panen}

Analisis ragam memperlihatkan perbedaan sangat nyata diantara genotipe-genotipe yang diuji berdasarkan karakter lama hari panen, sedangkan berdasarkan karakter indeks panen serempak tidak berpengaruh nyata. Lama hari panen berkisar antara 0-13 hari dengan rata-rata 6.63 hari, sedangkan indeks panen serempak berkisar antara 0.89-1 dengan rata-rata 0.95 (Tabel 5). 
Tabel 5. Hasil rataan lama hari panen dan indeks panen serempak dari 9 genotipe kacang hijau

\begin{tabular}{ccc}
\hline Genotipe & Lama hari panen (hari) & Indeks panen serempak \\
\hline KFM-1 & $6.67 \mathrm{~b}$ & $0.89 \mathrm{a}$ \\
KFM-2 & $6.67 \mathrm{~b}$ & $0.96 \mathrm{a}$ \\
LL1 & $6.67 \mathrm{~b}$ & $0.96 \mathrm{a}$ \\
LL2 & $4.00 \mathrm{~b}$ & $0.95 \mathrm{a}$ \\
LL3 & $6.67 \mathrm{~b}$ & $0.98 \mathrm{a}$ \\
LL4 & $9.33 \mathrm{a}$ & $0.89 \mathrm{a}$ \\
LWL & $0.00 \mathrm{~b}$ & $1.00 \mathrm{a}$ \\
MRT & $6.67 \mathrm{~b}$ & $0.98 \mathrm{a}$ \\
\hline Vima & $\mathbf{1 3 . 0 0} \mathbf{~ a}$ & $\mathbf{0 . 8 9} \mathbf{a}$ \\
\hline
\end{tabular}

Angka yang diikuti dengan huruf yang sama pada kolom yang sama menunjukkan hasil yang tidak berbeda nyata dengan pembanding Vima.

Hasil uji lanjut menunjukkan bahwa karakter lama hari panen berbeda nyata antara Vima dengan KFM-1, KFM-2, LL1, LL2, LL3, LWL, dan MRT. Genotipe LWL memiliki lama hari panen terbaik yaitu 0 hari, lebih cepat dibandingkan Vima dan rata-rata populasi. Selain itu genotipe lainnya memiliki rata-rata lama hari panen yang lebih singkat dibandingkan Vima. Menurut Gumabo (2007), selang panen kacang hijau berkisar antara 7-72 hari dengan nilai ratarata sebesar 34.78 hari. Pada karakter Indeks Panen Serempak (IPS) tidak terdapat perbedaan yang nyata antara genotipe yang diuji dengan Vima, walaupun secara deskriptif, genotipe LWL memiliki IPS paling baik yaitu 1, lebih baik dibandingkan Vima dan rata-rata populasi. Genotipe lainnya juga memiliki IPS yang relatif sama bahkan lebih baik dari Vima. Namun hasil penelitian ini tidak dalam keadaan normal, karena panenan yang dilakukan tidak maksimal akibat dari serangan cendawan embun tepung (Erysiphe polygoni). Serangan penyakit tersebut mempengaruhi produksi tanaman yang dihasilkan.

\section{Analisis Jarak Genetik}

Salah satu ciri yang dapat digunakan untuk mengukur keragaman plasma nutfah adalah penanda morfologi (morphology markers) yaitu sifat-sifat kualitatif pada tanaman yang dikendalikan oleh gen tunggal, maupun sifat-sifat kuantitatif yang secara genetik beragam. Pengaruh lingkungan sangat besar bagi penanda morfologi, namun bila sifat ini cukup tegar (robust) terhadap pengaruh lingkungan, masih dapat digunakan dalam analisis keanekaragaman genetik (Jambormias 2011).
Analisis gerombol (cluster analysis) merupakan suatu metode yang dapat digunakan untuk menyusun diagram jarak genetik (dendogram genetik). Analisis ini dilakukan dengan menentukan perbedaan diantara genotipegenotipe amatan. Analisis ini menggunakan jarak genetik (genetic distance) untuk menilai kesamaan genetik (genetic similarity) dua genotipe. Semakin kecil ukuran jarak genetik, maka semakin identik pula kedua genotipe. Sebaliknya semakin besar ukuran jarak genetik, maka semakin berbeda pula kedua genotipe (Jambormias 2011). Analisis jarak genetik genotipe-genotipe diuji berdasarkan karakter kuantitatif dan kualitatif.

\section{Jarak Genetik berdasarkan Karakter Kuantitatif}

Karakter kuantitatif yang dimasukkan kedalam perhitungan jarak genetik adalah yang memiliki pengaruh genotipe nyata yaitu: karakter umur berbunga 50\%, tinggi tanaman saat berbunga, tinggi tanaman saat panen terakhir, lama hari panen, dan jumlah polong bernas per tanaman.

Batasan jarak genetik bergantung pada jarak terbesar antar grup baru yang terbentuk, yaitu dipisahkan oleh garis putus-putus (Jambormias 2011). Hasil analisis gerombol menunjukkan bahwa terdapat empat kelompok berkerabat dekat. Kelompok pertama terdiri atas empat genotipe yaitu: LL1, MRT, KFM-2, dan LWL; kelompok kedua yaitu LL3; kelompok ketiga yaitu Vima; serta kelompok keempat terdiri atas tiga genotipe yaitu KFM-1, LL4, dan LL2 (Gambar 1). 


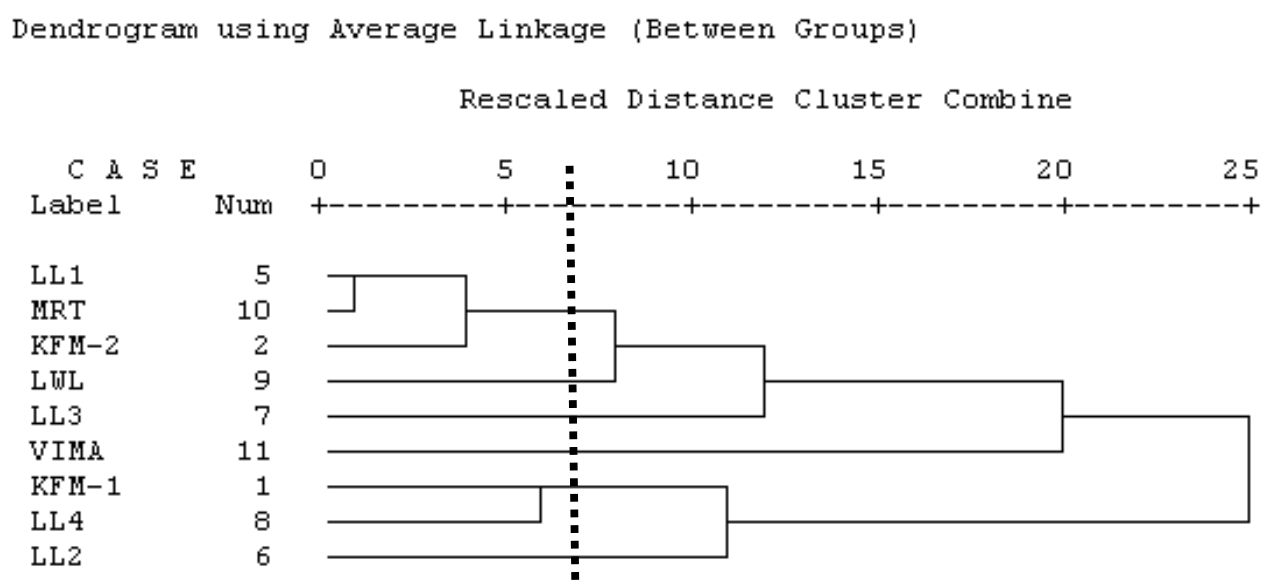

Gambar 1. Pengelompokan genotipe kacang hijau berdasarkan karakter kuantitatif

Genotipe-genotipe lokal yang terdapat dalam kelompok I memiliki karakteristik lama hari panen yang singkat, sedangkan kelompok II memiliki karakteristik umur berbunga 50\% dan jumlah polong bernas per tanaman terbaik. Kelompok IV memiliki karakteristik tinggi tanaman saat berbunga dan saat panen terakhir terbaik. Genotipe yang masuk dalam Kelompok III pada penelitian ini tidak memiliki keunggulan berdasarkan karakter kuantitatif. Walaupun demikian, kelompok III secara deskriptif memiliki karakteristik umur berbunga 100\% dan umur panen relatif terbaik.

Genotipe LL1 (Lombok, NTB) dan MRT (Kepulauan Meranti, Kepulauan Riau) memiliki kemiripan yang tinggi walaupun berasal dari daerah yang berbeda ditunjukkan dengan garis dendogram yang pendek. Genotipe tersebut diperkirakan memiliki kekerabatan yang sama karena walaupun berbeda daerah asal tetapi masih menunjukkan kesamaan karakter. Kemiripan genotipe tersebut dapat terjadi karena adanya kesamaan garis tetua atau kekerabatan yang dekat antar genotipe.

Terdapat empat genotipe yang berasal dari daerah yang sama (Lombok) yaitu LL1, LL2, LL3, dan LL4; tetapi keempat genotipe ini berada pada tiga kelompok yang berbeda. Genotipe LL2 berada pada kelompok pertama, LL3 berada pada kelompok kedua, sedangkan LL4 dan LL2 berada pada kelompok keempat. Berdasarkan analisis jarak genetik tidak terdapat genotipe yang satu kelompok dengan Vima. Berdasarkan potensi hasil dan analisis jarak genetik, dapat diketahui bahwa kelompok tiga termasuk kategori kelompok umur genjah dan kelompok satu termasuk kategori kelompok panen serempak. Hal ini dapat dijadikan pertimbangan untuk bahan tetua persilangan.

\section{Jarak Genetik berdasarkan Karakter Kualitatif}

Karakter kualitatif yang digunakan untuk analisis jarak genetik ini adalah warna hipokotil, warna mahkota bunga sebelum mekar, warna bunga, warna polong masak, dan kilau permukaan biji (Tabel 6). Karakter warna biji tidak dapat digunakan karena monomorfik. Warna biji berwarna hijau.

Hasil analisis gerombol menunjukkan bahwa terdapat tiga kelompok berkerabat dekat. Kelompok pertama terdiri atas enam genotipe yaitu: MRT, KFM-2, LKH, LWL, LL2, dan LL3; kelompok kedua terdiri atas dua genotipe yaitu LL1 dan LL4; serta kelompok ketiga terdiri atas dua genotipe yaitu KFM-1 dan Vima (Gambar 2).

Genotipe-genotipe lokal yang termasuk ke dalam kelompok I memiliki karakteristik warna mahkota bunga sebelum mekar dan hipokotil berwarna ungu. Kelompok II memiliki karakteristik warna mahkota bunga sebelum mekar dan hipokotil berwarna hijau, warna bunga berwarna kuning, warna polong masak berwarna hitam, serta kilau permukaan biji mengkilap. Terakhir, kelompok III memiliki karakteristik warna mahkota bunga sebelum mekar berwarna hijau, warna bunga berwarna kuning, warna polong masak berwarna hitam, serta kilau permukaan biji kusam. 
Tabel 6 Data karakter-karakter kualitatif dari 11 genotipe kacang hijau

\begin{tabular}{|c|c|c|c|c|c|c|}
\hline Genotipe & $\begin{array}{c}\text { Warna } \\
\text { hipokotil }\end{array}$ & $\begin{array}{l}\text { Warna mahkota bunga } \\
\text { sebelum mekar }\end{array}$ & $\begin{array}{l}\text { Warna } \\
\text { bunga }\end{array}$ & $\begin{array}{l}\text { Warna polong } \\
\text { masak }\end{array}$ & $\begin{array}{l}\text { Kilau permukaan } \\
\text { biji }\end{array}$ & $\begin{array}{c}\text { Warna } \\
\text { biji }\end{array}$ \\
\hline KFM-1 & Ungu & Hijau & Kuning & Hitam & Kusam & Hijau \\
\hline KFM-2 & Ungu & Ungu & Kuning & Hitam & Mengkilap & Hijau \\
\hline LKF & - & Ungu & $\begin{array}{l}\text { Kuning } \\
\text { muda }\end{array}$ & - & - & - \\
\hline LKH & Ungu & Ungu & $\begin{array}{l}\text { Kuning } \\
\text { muda }\end{array}$ & - & - & - \\
\hline LL1 & Hijau & Hijau & Kuning & Hitam & Mengkilap & Hijau \\
\hline LL2 & Ungu & Ungu & Kuning & Hitam & Kusam & Hijau \\
\hline LL3 & Ungu & Ungu & Kuning & Coklat & Kusam & Hijau \\
\hline LL4 & Hijau & Hijau & Kuning & Hitam & Mengkilap & Hijau \\
\hline LWL & Ungu & Ungu & Kuning & Coklat & Mengkilap & Hijau \\
\hline MRT & Ungu & Ungu & Kuning & Hitam & Mengkilap & Hijau \\
\hline Vima & Hijau & Hijau & Kuning & Hitam & Kusam & Hijau \\
\hline
\end{tabular}

Genotipe LWL (Maluku Selatan), MRT (Kepulauan Meranti, Kepulauan Riau), KFM-2 (Kefaminano, NTT), dan LKH (Maluku Selatan) memiliki kemiripan yang tinggi walaupun berasal dari daerah yang berbeda sebagaimana ditunjukkan dengan garis dendogram yang pendek. Kemiripan pada genotipe tersebut yaitu pada karakter warna hipokotil, warna mahkota bunga sebelum mekar, dan kilau permukaan biji. Genotipe tersebut diperkirakan memiliki kekerabatan yang sama, walaupun berbeda daerah asal tetapi masih menunjukkan kesamaan karakter. Kemiripan genotipe tersebut dapat terjadi karena adanya kesamaan garis tetua atau kekerabatan yang dekat antar genotipe.
Terdapat empat genotipe yang berasal dari daerah yang sama (Lombok) yaitu LL1, LL2, LL3, dan LL4; tetapi keempat genotipe ini berada pada dua kelompok yang berbeda. Genotipe LL2 dan LL3 berada pada kelompok pertama sedangkan LL1 dan LL4 berada pada kelompok kedua. Keempat genotipe Lombok ini dibedakan berdasarkan karakter warna hipokotil, warna mahkota bunga sebelum mekar, dan kilau permukaan biji. Berdasarkan analisis jarak genetik untuk karakter kualitatif terdapat genotipe yang satu kelompok dengan Vima yaitu KFM-1. Genotipe KFM-1 memiliki kesamaan dengan Vima pada karakter warna mahkota bunga sebelum mekar, warna bunga, warna polong masak, dan kilau permukaan biji.

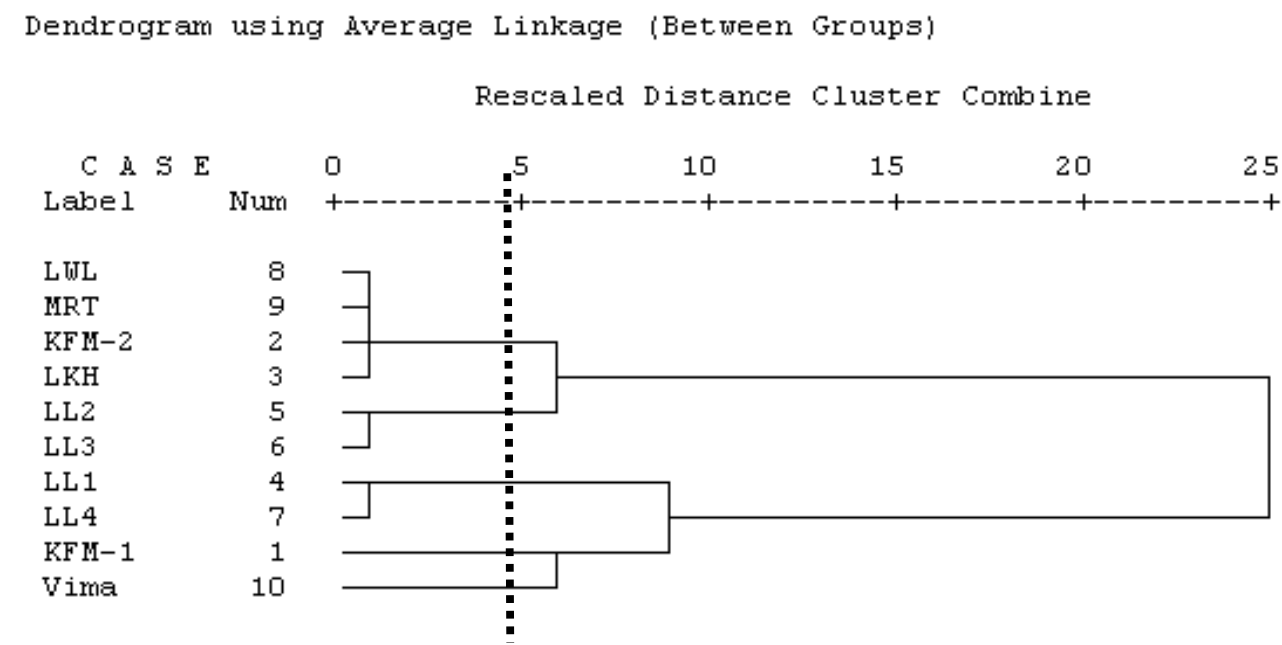

Gambar 2. Pengelompokan genotipe kacang hijau berdasarkan karakter kualitatif 
Hasil dendogram menunjukkan terjadi perbedaan kelompok yang terbentuk antara karakter kuantitatif dengan kualitatif. Pada karakter kuantitatif terbentuk empat kelompok berkerabat dekat sedangkan pada karakter kualitatif terbentuk tiga kelompok berkerabat dekat. Anggota kelompok berdasarkan karakter kualitatif berbeda dengan karakter kuantitatif, sehingga kedua pengelompokan ini tidak searah. Hasil ini mengindikasikan bahwa karakter kualitatif tidak dapat digunakan sebagai indikator untuk mengevaluasi keunggulan genotipegenotipe berdasarkan karakter kuantitatif.

Perbedaan pengelompokan diduga dipengaruhi oleh lingkungan, karena pengaruh lingkungan sangat besar bagi penanda morfologi terutama untuk karakter kuantitatif. Pengetahuan hubungan kekerabatan kacang hijau ini dapat digunakan sebagai bahan pertimbangan pemulia kacang hijau dalam merakit varietas unggul baru. Persilangan diantara genotipe yang memiliki kemiripan kecil (berada dalam kelompok yang berbeda) akan lebih berpeluang dalam menghasilkan keragaman genetik.

\section{KESIMPULAN}

\begin{abstract}
Genotipe-genotipe berbeda nyata berdasarkan pembandingan komponen pertumbuhan (karakter tinggi tanaman), komponen umur tanaman (karakter umur berbunga 50\%), serta komponen produksi (karakter jumlah polong bernas per tanaman dan jumlah biji bernas per tanaman). Genotipe LL3 merupakan genotipe terbaik, dengan jumlah polong bernas per tanaman sebesar 12 polong, jumlah biji bernas per tanaman sebesar 81 biji, serta umur berbunga $50 \%$ sebesar 34 hari, diikuti genotipe LL4 dengan bobot 100 butir sebesar 5.25 gram; genotipe LWL dengan lama hari panen sebesar 0 hari serta indeks panen serempak sebesar 1; dan genotipe LKH dengan tinggi tanaman saat berbunga sebesar $67 \mathrm{~cm}$ serta tinggi tanaman saat panen terakhir sebesar $86.1 \mathrm{~cm}$.
\end{abstract}

Berdasarkan analisis jarak genetik, genotipe-genotipe yang diuji dapat mengelompok menjadi empat kelompok (berdasarkan karakter kuantitatif) dan tiga kelompok (berdasarkan karakter kualitatif). Kedua pengelompokan ini tidak searah, sehingga pengelompokan berdasarkan karakter kualitatif tidak dapat digunakan sebagai indikator untuk mengevaluasi keunggulan genotipe-genotipe berdasarkan karakter kuantitatif.Berdasarkan potensi hasil dan analisis jarak genetik berdasarkan karakter kuantitatif, dapat diketahui bahwa kelompok tiga (Vima) termasuk kategori kelompok umur genjah dan kelompok satu (LL1, MRT, KFM-2, dan LWL) termasuk kategori kelompok panen serempak.

\section{DAFTAR PUSTAKA}

Anwari M, Iswanto R. 2004. Stabilitas hasil galur harapan kacang hijau. Di dalam: AK Makarim, Marwoto, MM Adie, AA Rahmianna, Heriyanto, IK Tastra, editor. Kinerja Penelitian Mendukung Agribisnis Kacang-kacangan dan Umbi-umbian; 2004 Okt 5; Malang, Indonesia. Bogor (ID): Pusat Penelitian dan Pengembangan Tanaman Pangan. hlm 214-219.

Anwari M, Soehendi R, Iswanto R, Sumartini, Purnomo H, Supeno A. 2008. Galur MMC157d-Kp-1: Calon varietas unggul kacang hijau umur genjah, dan tahan penyakit embun tepung. Di dalam: A Harsono, A Taufiq, AA Rahmianna, Suharsono, MM Adie, F Rozi, A Wijanarko, A Widjono, R Soehendi, editor. Inovasi Teknologi Kacang-kacangan dan Umbi-umbian: Mendukung Kemandirian Pangan dan Kecukupan Energi; 2007 Nov 9; Malang, Indonesia. Bogor (ID): Balai Penelitian Tanaman Kacang-kacangan dan Umbi-umbian. hlm 173-182.

[BPS] Badan Pusat Statistik. 2012. Tanaman Pangan [Internet]. [diunduh 2012 Mar 07]. Tersedia pada: http://www.bps.go.id/tnmn_pgn.php?kat=3.

Gumabo AWSS. 2007. Kajian Genetik dan Seleksi Genotipe S5 Kacang Hijau (Vigna radiata (L.) Wilczek) menuju Varietas Berdaya Hasil Tinggi dan Serempak Panen [Skripsi]. Bogor (ID): Institut Pertanian Bogor.

Hilman Y. 2005. Teknologi Produksi Kacangkacangan dan Umbi-umbian. Malang (ID): Balai Penelitian Tanaman Kacangkacangan dan Umbi-umbian.
Jambormias
E. 2011.
Pengukuran Keanekaragaman Genetik [Internet]. [diunduh 2013 Agu 26]. Tersedia pada: http://www.agrostatfapertaunpatti.blogspot. com/2011/07/pengukuran-keanekaragaman- plasma-nutfah.html 
Jambormias E, Tutupary JM, Patty JR. 2013. Analisis dialel sifat berganda pada kacang hijau (Vigna radiata L. Wilczek). Agrinimal 3(1):23-29.

Khattak GSS, Haq MA, Ashraf M, Tahir GR. 2001. Genetic basis of synchrony in pod maturity in mungbean (Vigna radiata (L.) Wilczek). Kasetsart J. (Nat. Sci.) 35:1-7.

Khattak GSS, Ashraf M, Zamir R. 2004. Gene action for synchrony in pod maturity and indeterminate growth habit in mungbean (Vigna radiata (L.) Wilczek). Pak J. Bot. 36(3):589-594.

Lawn RJ, Imrie BC. 1991. The Australian mungbean industry in perspective. Proceeding of the First Australian Mungbean Workshop Brisbane. Brisbane (AU): Grain Legumes Research Council, Australian Mungbean Association, CallideDawson Seedgrowers Cooperative, Westpac Banking Corporation. hlm 3-6.

Musalamah, M Anwari. 2007. Hubungan kekerabatan antar aksesi kacang hijau berdasarkan karakter kuantitatif. Di dalam: D Harnowo, AA Rahmiana, Suharsono, MM Adie, F Rozi, Subandi, AK Makarim, editor. Peningkatan Produksi Kacangkacangan dan Umbi-umbian Mendukung Kemandirian Pangan; 2006 Sept 8; Malang, Indonesia. Bogor (ID): Pusat Penelitian dan Pengembangan Tanaman Pangan. hlm 134-144.

[PPI] Panduan Pengujian Individual. 2007. Panduan Pengujian Individual Kebaruan, Keunikan, Keseragaman dan Kestabilan. Departemen Pertanian Republik Indonesia, Pusat Perlindungan Varietas Tanaman.

Purwono, Purnamawati H. 2008. Budidaya 8 Jenis Tanaman Pangan Unggul. Jakarta (ID): Penebar Swadaya. 137 hlm.

[Puslittan] Pusat Penelitian dan Pengembangan Tanaman Pangan. 2012a. VIMA 1, VUB kacang hijau umur genjah, masak serempak, dan tahan penyakit embun tepung [Internet]. [diunduh 2012 Mar 07]. Tersedia pada: http://www.puslittan.bogor.net/index.php?b awaan=berita/fullteks_berita\&id $=87$. 